\title{
Review \\ PD-L1, TMB, MSI, and Other Predictors of Response to Immune Checkpoint Inhibitors in Biliary Tract Cancer
}

\author{
Alessandro Rizzo *, Angela Dalia Ricci and Giovanni Brandi \\ Division of Oncology, IRCCS Azienda Ospedaliero-Universitaria di Bologna, 40138 Bologna, Italy; \\ angeladalia.ricci@studio.unibo.it (A.D.R.); giovanni.brandi@unibo.it (G.B.) \\ * Correspondence: alessandro.rizzo11@studio.unibo.it
}

Citation: Rizzo, A.; Ricci, A.D.; Brandi, G. PD-L1, TMB, MSI, and Other Predictors of Response to Immune Checkpoint Inhibitors in Biliary Tract Cancer. Cancers 2021, 13, 558. https://doi.org/10.3390/ cancers 13030558

Academic Editor: David Wong

Received: 4 January 2021

Accepted: 28 January 2021

Published: 1 February 2021

Publisher's Note: MDPI stays neutral with regard to jurisdictional claims in published maps and institutional affiliations.

Copyright: (c) 2021 by the authors. Licensee MDPI, Basel, Switzerland. This article is an open access article distributed under the terms and conditions of the Creative Commons Attribution (CC BY) license (https:// creativecommons.org/licenses/by/ $4.0 /)$.
Simple Summary: Over the last decade, immune checkpoint inhibitors (ICIs) targeting programmed death 1 (PD-1), programmed death-ligand 1 (PD-L1), and cytotoxic T-lymphocyte antigen 4 (CTLA-4) have dramatically changed the therapeutic algorithm of several hematological and solid tumors. Of note, these agents have been also investigated in biliary tract cancer (BTC), reporting controversial results so far; in this setting, the role of ICIs is still to be established, and available data on immunotherapy in BTC patients are mainly limited to sub-analyses of basket trials and small single-arm studies. A crucial challenge is represented by the lack of validated predictive biomarkers, that could help identify responders to immunotherapy, a high unmet need in these immunologically "cold" malignancies where ICIs are still looking for their niche.

Abstract: Biliary tract cancer (BTC) represents the second most frequently diagnosed primary liver cancer worldwide following hepatocellular carcinoma, and the overall survival of patients with unresectable disease remains poor. In recent years, the advent of immune checkpoint inhibitors (ICIs) has revolutionized the therapeutic landscape of several malignancies with these agents, which have also been explored in advanced BTC, as monotherapy or in combination with other anticancer agents. However, clinical trials evaluating ICIs in BTC have shown conflicting results, and the clinical benefit provided by immunotherapy seems limited to a small subgroup of BTC patients. Thus, the identification of reliable predictors of the response to immunotherapy represents a significant challenge in this setting. This review provides an overview of the available evidence on the biomarkers predictive of the response to ICIs in patients with advanced BTC, especially focusing on programmed death-ligand 1 (PD-L1), tumor mutational burden (TMB), microsatellite instability (MSI), and other emerging biomarkers.

Keywords: predictive biomarkers; PD-L1; TMB; immunotherapy; immune checkpoint inhibitors; biliary tract cancer; cholangiocarcinoma

\section{Introduction}

Biliary tract cancers (BTCs) encompass a group of aggressive, rare, and heterogeneous tumors arising in the bile duct system, comprising gallbladder cancer (GBC), ampulla of Vater cancer (AVC), and cholangiocarcinoma (CCA) [1,2]. CCA is classically divided into extrahepatic cholangiocarcinoma (eCCA), originating outside the liver and further subclassified into distal (dCCA) and perihilar cholangiocarcinoma (pCCA), and intrahepatic cholangiocarcinoma (iCCA), occurring within the liver parenchyma [3,4]. Of note, this classification-based on the anatomical location of BTCs within the biliary tree-mirrors remarkable differences in terms of tumor biology, molecular features, epidemiology, prognosis, and therapeutic approaches [5].

BTC represents the second most frequent hepatobiliary tumor following hepatocellular carcinoma (HCC), accounting for approximately $3 \%$ of all gastrointestinal malignancies worldwide [6]. Although BTCs have been traditionally considered rare tumors, their 
overall incidence has seen a remarkable increase over recent decades in most Western countries [7]. Radical surgery remains the only potentially curative treatment option, but unfortunately, most patients with BTC are diagnosed with advanced disease; moreover, a non-negligible proportion of BTCs initially considered resectable are subsequently found to be unresectable during exploratory laparotomy [8,9]. Additionally, even following surgical resection with negative tumor margins, distant and locoregional recurrence rates are high. In BTC patients with metastatic disease, systemic treatments represent the only potential therapeutic option. More than ten years after the publication of the landmark ABC-02 phase III trial, the combination of gemcitabine plus cisplatin remains the current standard of care in treatment-naïve patients $[10,11]$. According to the results of this study, the gemcitabine-cisplatin combination showed superior median overall survival (OS) compared to gemcitabine monotherapy (11.7 months versus 8.2 months, respectively; hazard ratio (HR), $0.64 ; 95 \%$ confidence interval $(\mathrm{CI}), 0.52-0.80 ; p<0.001$ ), with the ABC02 establishing gemcitabine-cisplatin as the reference doublet $[10,11]$. Nonetheless, the limited survival benefit provided by systemic treatments has highlighted the need for more effective medical therapies in this setting [12].

The last decade has registered important advances in the understanding of the tumor biology of BTCs, as witnessed by the parallel development of novel treatment options and genomic sequencing, which has paved the way toward the identification of several possible therapeutic targets [13-15]. In fact, molecularly targeted therapies have been tested in BTC patients harboring specific druggable alterations, especially in iCCAs where agents targeting isocitrate dehydrogenase (IDH) mutations and fibroblast growth factor receptor (FGFR) aberrations have entered into clinical practice [16-22]; in addition, following the results observed in several hematological and solid malignancies, immune checkpoint inhibitors (ICIs) have been explored and are currently being investigated in BTC (Table 1) [23-25]. However, most BTC patients receiving ICIs as a monotherapy or in combination with other anticancer agents do not achieve response, and the mechanisms behind the variations in the response to immunotherapy in this setting have been poorly studied [26]. Based on these premises, the identification of biomarkers able to predict responses to ICIs and the understanding of resistance mechanisms in non-responders represent high unmet needs.

Herein, we provide an overview on the current knowledge regarding the predictive biomarkers of the response to ICIs in advanced BTCs, especially focusing on the role of programmed death-ligand 1 (PD-L1) expression, tumor mutational burden (TMB), mismatch repair deficiency (dMMR), high microsatellite instability (MSI-H), and DNA damage repair (DDR) gene mutations in this setting.

We performed research using PubMed/Medline, Cochrane Library, and Scopus with the keywords "biliary tract cancer" OR "cholangiocarcinoma" OR "intrahepatic cholangiocarcinoma" OR "extrahepatic cholangiocarcinoma" OR "gallbladder cancer" AND "immunotherapy" OR "immune checkpoint inhibitors" AND "PD-L1" OR "tumor mutational burden" OR “TMB" OR “MSI" OR “DDR" OR “DNA damage repair" OR "tumor microenvironment." We selected pivotal registration studies. We also selected the most relevant and pertinent studies considering the quality of the studies in terms of their applicability, how they were conducted, statistical analysis, number of patients enrolled, and outcomes. For ongoing clinical trials, we searched in the clinicaltrials.gov database for currently recruiting and active trials, not simply recruiting trials, using the following keywords: "biliary tract cancer" OR "cholangiocarcinoma" OR "intrahepatic cholangiocarcinoma" OR "extrahepatic cholangiocarcinoma" OR "gallbladder cancer" AND "immunotherapy" OR "immune checkpoint inhibitors." We restricted our research to phase I, II, or III trials focused on the metastatic/advanced setting. 
Table 1. Ongoing phase I to III clinical trials evaluating immune checkpoint inhibitors in biliary tract cancer patients with advanced disease.

\begin{tabular}{|c|c|c|c|c|c|c|c|}
\hline NCT Name & Phase & $\begin{array}{c}\text { Setting } \\
\text { (Type of BTC) }\end{array}$ & Arm A & Arm B & Agents Description & Primary Outcomes & $\begin{array}{c}\text { Estimated } \\
\text { Enrollment }\end{array}$ \\
\hline NCT04066491 & II/III & $\begin{array}{c}\text { First-line (iCCA, } \\
\text { eCCA, GBC) }\end{array}$ & $\begin{array}{c}\text { Bintrafusp alfa } \\
\text { (M7824) plus CisGem }\end{array}$ & $\begin{array}{l}\text { Placebo plus } \\
\text { CisGem }\end{array}$ & $\begin{array}{l}\text { Bintrafusp alfa: first-in-class } \\
\text { bifunctional fusion protein } \\
\text { composed by a PD-L1 antibody } \\
\text { fused with } 2 \text { extracellular domains } \\
\text { of TGF- } \beta \text { receptor }\end{array}$ & $\begin{array}{c}\text { DLTs } \\
\text { OS }\end{array}$ & 512 \\
\hline $\begin{array}{l}\text { NCT03875235 } \\
\text { (TOPAZ-1) }\end{array}$ & III & $\begin{array}{l}\text { First-line (iCCA, } \\
\text { eCCA, GBC) }\end{array}$ & $\begin{array}{l}\text { Durvalumab plus } \\
\text { CisGem }\end{array}$ & $\begin{array}{l}\text { Placebo plus } \\
\text { CisGem }\end{array}$ & Durvalumab: PD-L1 inhibitor & OS & 757 \\
\hline NCT03260712 & II & $\begin{array}{c}\text { First-line (iCCA, } \\
\text { eCCA, GBC) }\end{array}$ & $\begin{array}{l}\text { Pembrolizumab plus } \\
\text { CisGem }\end{array}$ & & Pembrolizumab: PD-1 antibody & PFS at 6 months & 50 \\
\hline NCT04300959 & II & $\begin{array}{c}\text { First-line (iCCA, } \\
\text { eCCA, GBC) }\end{array}$ & $\begin{array}{l}\text { Anlotinib plus } \\
\text { sintilimab plus } \\
\text { CisGem }\end{array}$ & CisGem & $\begin{array}{l}\text { Anlotinib: TKI inhibiting PDGFR, } \\
\text { FGFR, VEGFR and c-KIT kinase } \\
\text { Sintilimab: PD-1 antibody }\end{array}$ & 12-month OS rate & 80 \\
\hline NCT03046862 & II & $\begin{array}{c}\text { First-line (AVC, } \\
\text { iCCA, eCCA, GBC) }\end{array}$ & $\begin{array}{l}\text { Durvalumab plus } \\
\text { tremelimumab plus } \\
\text { CisGem }\end{array}$ & & $\begin{array}{c}\text { Durvalumab: PD-L1 inhibitor } \\
\text { Tremelimumab: } \\
\text { anti-CTLA-4 agent }\end{array}$ & ORR & 31 \\
\hline NCT04172402 & II & $\begin{array}{c}\text { First-line (AVC, } \\
\text { iCCA, eCCA, GBC) }\end{array}$ & $\begin{array}{l}\text { Nivolumab plus S-1 } \\
\text { plus gemcitabine }\end{array}$ & & Nivolumab: PD-1 antibody & ORR & 48 \\
\hline NCT04027764 & II & $\begin{array}{c}\text { First-line (iCCA, } \\
\text { eCCA, GBC) }\end{array}$ & $\begin{array}{c}\text { Toripalimab plus S-1 } \\
\text { plus albumin } \\
\text { paclitaxel }\end{array}$ & & Toripalimab: PD-1 antibody & ORR & 30 \\
\hline NCT03478488 & III & $\begin{array}{l}\text { First-line (iCCA, } \\
\text { eCCA, GBC) }\end{array}$ & KN035 plus GEMOX & GEMOX & KN035: PD-L1 inhibitor & OS & 390 \\
\hline NCT04191343 & II & $\begin{array}{l}\text { First-line (iCCA, } \\
\text { eCCA, GBC) }\end{array}$ & $\begin{array}{c}\text { Toripalimab plus } \\
\text { GEMOX }\end{array}$ & & Toripalimab: PD-1 antibody & ORR & 20 \\
\hline
\end{tabular}


Table 1. Cont.

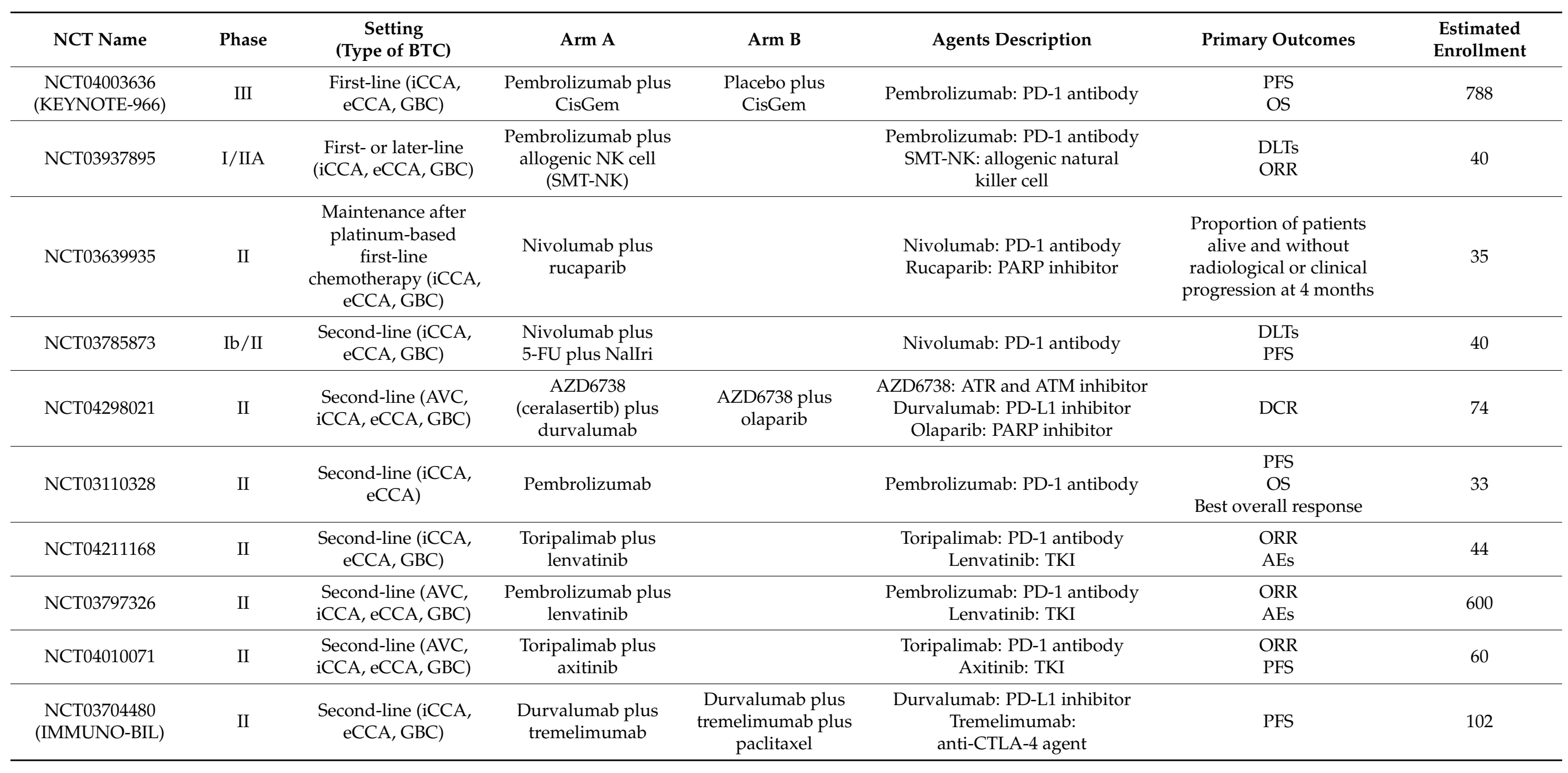


Table 1. Cont.

\begin{tabular}{|c|c|c|c|c|c|c|c|}
\hline NCT Name & Phase & $\begin{array}{c}\text { Setting } \\
\text { (Type of BTC) }\end{array}$ & Arm A & Arm B & Agents Description & Primary Outcomes & $\begin{array}{c}\text { Estimated } \\
\text { Enrollment }\end{array}$ \\
\hline $\begin{array}{l}\text { NCT04003636 } \\
\text { (KEYNOTE-966) }\end{array}$ & III & $\begin{array}{l}\text { First-line (iCCA, } \\
\text { eCCA, GBC) }\end{array}$ & $\begin{array}{l}\text { Pembrolizumab plus } \\
\text { CisGem }\end{array}$ & $\begin{array}{l}\text { Placebo plus } \\
\text { CisGem }\end{array}$ & Pembrolizumab: PD-1 antibody & $\begin{array}{l}\text { PFS } \\
\text { OS }\end{array}$ & 788 \\
\hline NCT03937895 & I/IIA & $\begin{array}{l}\text { First- or later-line } \\
\text { (iCCA, eCCA, GBC) }\end{array}$ & $\begin{array}{l}\text { Pembrolizumab plus } \\
\text { allogenic NK cell } \\
\text { (SMT-NK) }\end{array}$ & & $\begin{array}{l}\text { Pembrolizumab: PD-1 antibody } \\
\text { SMT-NK: allogenic natural } \\
\text { killer cell }\end{array}$ & $\begin{array}{l}\text { DLTs } \\
\text { ORR }\end{array}$ & 40 \\
\hline NCT03999658 & II & $\begin{array}{l}\text { Second- or later-line } \\
\text { (AVC, iCCA, } \\
\text { eCCA, GBC) }\end{array}$ & STI-3031 & & STI-3031: PD-L1 inhibitor & ORR & 220 \\
\hline NCT03475953 & $\mathrm{I} / \mathrm{II}$ & $\begin{array}{l}\text { Second- or later-line } \\
\text { (AVC, iCCA, } \\
\text { eCCA, GBC) }\end{array}$ & $\begin{array}{l}\text { Avelumab plus } \\
\text { regorafenib }\end{array}$ & & $\begin{array}{l}\text { Avelumab: PD-L1 inhibitor } \\
\text { Regorafenib: TKI }\end{array}$ & RP2D & 362 \\
\hline NCT03801083 & II & $\begin{array}{l}\text { Second- or later-line } \\
\text { (AVC, iCCA, } \\
\text { eCCA, GBC) }\end{array}$ & TILs & & $\begin{array}{l}\text { TILs: Tumor-Infiltrating } \\
\text { Lymphocytes }\end{array}$ & ORR & 59 \\
\hline NCT04057365 & II & $\begin{array}{l}\text { Second- or later-line } \\
\text { (iCCA, eCCA, GBC) }\end{array}$ & $\begin{array}{l}\text { Nivolumab plus } \\
\text { DKN-01 }\end{array}$ & & $\begin{array}{c}\text { Nivolumab: PD-1 antibody } \\
\text { DKN-01: humanized monoclonal } \\
\text { antibody against the } \\
\text { DKK1 protein }\end{array}$ & ORR & 30 \\
\hline NCT04298008 & II & $\begin{array}{l}\text { Third-line (AVC, } \\
\text { iCCA, eCCA, GBC) }\end{array}$ & $\begin{array}{c}\text { AZD6738 } \\
\text { (ceralasertib) plus } \\
\text { durvalumab }\end{array}$ & & $\begin{array}{l}\text { AZD6738: ATR and ATM inhibitor } \\
\text { Durvalumab: PD-L1 inhibitor }\end{array}$ & DCR & 26 \\
\hline
\end{tabular}

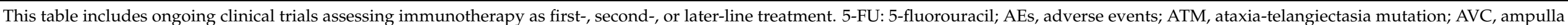

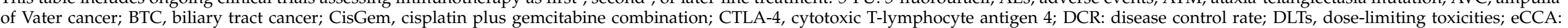

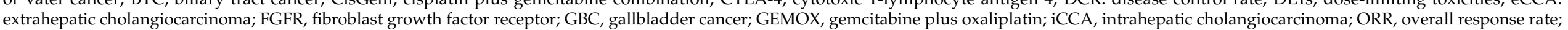

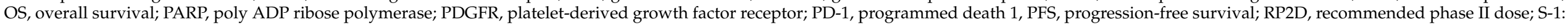
tegafur/gimeracil/oteracil; TILs: tumor infiltrating lymphocytes; TKI, tyrosine kinase inhibitor; VEGFR, vascular endothelial growth factor. 


\section{PD-L1 Expression}

The expression of PD-L1 assessed by immunohistochemistry has been shown to correlate with response to ICIs in several tumor types, including non-small cell lung cancer (NSCLC), gastric cancer, and urothelial carcinoma [27-29]. However, few data are available in BTC patients treated with ICIs so far. According to previous reports, PD-L1 expression has been reported to range from approximately $45 \%$ to $65 \%$ of immune cells within the tumor microenvironment and from $10 \%$ to $70 \%$ of tumor specimens [30,31]; in addition, PD-L1 expression by both intra-tumoral inflammatory or neoplastic cells has been related to tumor aggressiveness and worse survival [32,33]. First, Gani and colleagues evaluated the association between clinical outcomes and PD-L1 expression in 54 iCCA tumor samples, with PD-L1 assessed within the tumor front (TF) and in tumor-associated macrophages (TAMs) [34]. Of note, iCCAs expressing PD-L1 in the TF had a $60 \%$ reduced survival compared to PD-L1-negative patients [34]. Similar results were mirrored in more recent studies on other BTC subtypes, including PCCA and dCCA [30-33].

Regarding the predictive value of PD-L1 in this setting, interesting data may be extracted by the subgroup analyses of clinical trials assessing ICIs in advanced BTCs [35]. Among these, the KEYNOTE-028 phase Ib trial (Table 2) exclusively enrolled PD-L1-positive patients, with at least a $1 \%$ modified proportion score or interface pattern, which were treated with $10 \mathrm{mg} / \mathrm{kg}$ of pembrolizumab every two weeks [36]. According to the results of this study, after a median follow-up of 7.5 months, the overall response rate (ORR) was $13.0 \%$ in 23 previously treated BTC patients, with a median progression-free survival (PFS) and an overall survival (OS) of 1.8 and 5.7 months, respectively [36]. Similarly, the KEYNOTE-158 phase II trial investigated the role of $200 \mathrm{mg}$ of pembrolizumab every three weeks in pretreated BTC patients with advanced disease [36]. At a median follow-up of 5.7 months in the overall population, a disappointing ORR of $5.8 \%$ was detected, with median PFS and OS of 2.0 and 7.4 months, respectively [36]. In a subgroup analysis especially focused on PD-L1-positive $(n=61)$ and PD-L1-negative $(n=34)$ BTC patients, the ORR was $6.6 \%$ in the first group and $2.9 \%$ in PD-L1-nonexpressers [36].

Another PD-1 inhibitor, nivolumab, was evaluated as a second-line treatment in 54 BTC patients with advanced disease in a recently published phase II trial [37]. In this study conducted by Kim and colleagues, the median PFS and OS in the overall population were 3.7 and 14.2 months, respectively, with an ORR of $22 \%$ and disease control rate (DCR) of $59 \%$ (Table 2). In 18 PD-L1-positive patients ( $\geq 1 \%$ of tumor cells expressing PD-L1 as a cutoff), a statistically significantly superior median PFS was observed compared to PD-L1negative BTCs (10.4 months versus 2.3 months; HR, 0.23; 95\% CI, 0.10-0.51; $p<0.001$ ) [37]. In addition, a clinically meaningful superior median OS was observed in PD-L1-positive patients, despite not reaching statistical significance (not reached versus 10.8 months) [37].

Overall, the role of PD-L1 expression in predicting the response to ICIs in BTC is still to be defined. In addition, several methodological issues must be taken into account when discussing this topic in BTC, as well as in other tumor types [38,39]. Among these, the use of different PD-L1 assays, the lack of guidelines, the differences in scoring systems, and the discrepancy between metastatic and primary lesions have been suggested to be implied in reporting discordant results. 
Table 2. Reported outcomes of single-agent immune checkpoint inhibitors in advanced biliary tract cancer (BTC).

\begin{tabular}{|c|c|c|c|c|c|}
\hline Phase & $\begin{array}{c}\text { Setting, } \\
\text { (Type of BTC) }\end{array}$ & ICI & Agents Description & $\begin{array}{c}\text { Number of } \\
\text { Patients }\end{array}$ & Outcomes \\
\hline $\mathrm{Ib}[36]$ & $\begin{array}{l}\text { Second- or later-line } \\
\text { (iCCA, eCCA, GBC) }\end{array}$ & Pembrolizumab & $\begin{array}{l}\text { Pembrolizumab: } \\
\text { PD-1 inhibitor }\end{array}$ & $\begin{array}{l}24 \text { (all patients had } \\
\quad \text { PD-L1 } \geq 1 \% \text { ) }\end{array}$ & $\begin{array}{c}\text { mPFS } 1.8 \text { months } \\
\text { mOS } 5.7 \text { months } \\
\text { ORR } 13 \% \\
\text { SD rate } 17 \%\end{array}$ \\
\hline II [36] & $\begin{array}{l}\text { Second- or later-line } \\
\text { (iCCA, eCCA, GBC) }\end{array}$ & Pembrolizumab & $\begin{array}{l}\text { Pembrolizumab: } \\
\text { PD-1 inhibitor }\end{array}$ & $\begin{array}{l}104 \text { (61 patients } \\
\text { had PD-L1 } \geq 1 \% \text { ) }\end{array}$ & $\begin{array}{l}\text { mPFS } 2.0 \text { months } \\
\text { mOS } 7.4 \text { months } \\
\text { ORR } 5.8 \%(6.6 \% \text { in } \\
\text { PD-L1+; } 2.9 \% \text { in } \\
\text { PD-L1-) }\end{array}$ \\
\hline II [40] & $\begin{array}{l}\text { Second- or later-line } \\
\text { (iCCA, eCCA, GBC) }\end{array}$ & Nivolumab & $\begin{array}{l}\text { Nivolumab: PD-1 } \\
\text { inhibitor }\end{array}$ & 30 & $\begin{array}{c}\text { mPFS } 1.4 \text { months } \\
\text { mOS } 5.2 \text { months } \\
\text { PR rate } 3 \%\end{array}$ \\
\hline II [37] & $\begin{array}{l}\text { Second- or later-line } \\
\text { (iCCA, eCCA, GBC) }\end{array}$ & Nivolumab & $\begin{array}{l}\text { Nivolumab: PD-1 } \\
\text { inhibitor }\end{array}$ & 54 & $\begin{array}{c}\text { mPFS } 3.7 \text { months } \\
\text { mOS } 14.2 \text { months } \\
\text { ORR } 22 \% \\
\text { DCR } 50 \%\end{array}$ \\
\hline II [41] & $\begin{array}{l}\text { Second- or later-line } \\
\text { (iCCA, eCCA, GBC) }\end{array}$ & Durvalumab & $\begin{array}{l}\text { Durvalumab: PD-L1 } \\
\text { inhibitor }\end{array}$ & 42 & $\begin{array}{c}\text { mPFS } 1.5 \text { months } \\
\text { mOS } 8.1 \text { months } \\
\text { PR rate } 4.8 \%\end{array}$ \\
\hline I [42] & $\begin{array}{l}\text { Second- or later-line } \\
\text { (iCCA, eCCA, GBC) }\end{array}$ & M7824 & $\begin{array}{l}\text { M7824: PD-L1 } \\
\text { inhibitor }\end{array}$ & 30 & $\begin{array}{l}\text { mOS } 12.7 \text { months } \\
\text { ORR } 20 \%\end{array}$ \\
\hline
\end{tabular}

AVC, ampulla of Vater cancer; DCR, disease control rate; eCCA, extrahepatic cholangiocarcinoma; GBC, gallbladder cancer; iCCA, intrahepatic cholangiocarcinoma; m, median; ORR, overall response rate; OS, overall survival; PD-1, programmed death 1; PFS, progressionfree survival; $\mathrm{PR}$, partial response; $\mathrm{SD}$, stable disease.

\section{TMB}

Besides PD-L1 expression, TMB has been associated with responses to ICIs in several tumor types, despite this biomarker not having been prospectively validated yet [43]. TMB is commonly defined as the overall number of somatic nonsynonymous mutations per megabase (Mut/Mb), including frame-shift mutations, insertions, point mutations, and deletions [44,45]. The onset of these mutations is involved in the synthesis of abnormal proteins, which can act as neoantigens, activating antitumor responses (Figure 1) [46].

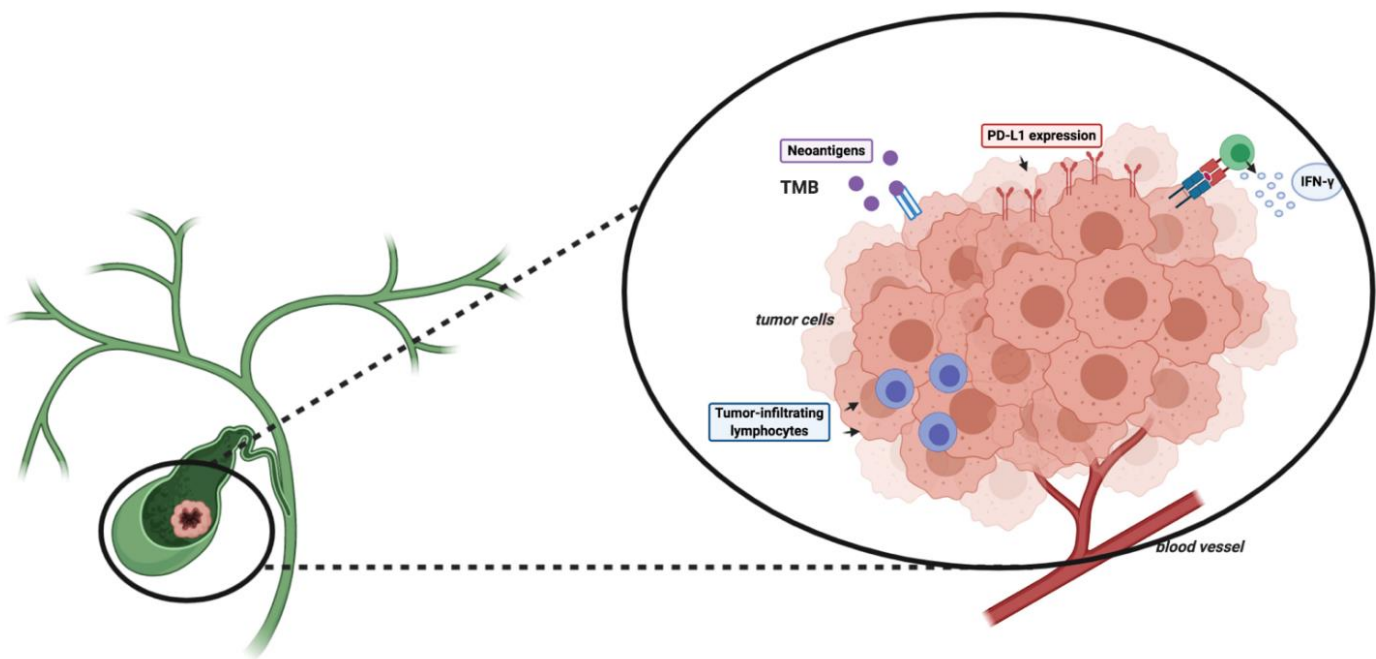

Figure 1. Schematic figure reporting some potential biomarkers of the response to immune checkpoint inhibitors (ICIs). Abbreviations: TMB, tumor mutational burden; PD-1, programmed death 1; PD-L1, programmed death-ligand 1. 
As in the case of PD-L1, TMB assessment is widely influenced by the kits and methods used that have been suggested to report different values in the same sample, and consequently, great attention and caution should be paid when comparing TMB values between studies using different methods $[47,48]$. In a genomic study by Weinberg and colleagues on 1502 BTCs, TMB was investigated in 352 tumor samples [49]. Based on a cutoff of $17 \mathrm{Mut} / \mathrm{Mb}$, the authors observed that $4 \%$ of samples (14/352) had high TMB (TMB-H) [49]; of note, the proportion of TMB-H tumors was different in distinct BTC subgroups, with 5.8\% (6/104), 3.5\% (7/198), and $\%$ (1/50) of GBCs, iCCAs, and eCCAs, defined as TMB-H in this genomic report [49].

In terms of clinical responses to ICIs, data on TMB in BTC are sparse and anecdotal. A recently published study by Zhang and colleagues reported three BTC cases (one iCCA and two dCCAs) with TMB-H, which were treated with ICIs [50]; of note, all of these patients achieved response to immunotherapy, with two partial responses (PRs) and one case of complete response (CR) [50]. However, recent phase I and II clinical trials evaluating ICIs in advanced BTC did not report data in terms of TMB. Further studies are needed to understand the putative role of TMB in predicting the response to ICIs in BTC patients [50].

\section{4. $\mathrm{dMMR/MSI-H}$}

In addition to PD-L1 and TMB, MSI is considered a potentially meaningful predictive biomarker of the response to ICIs, and has been associated with dMMR [51]. More specifically, MSI results in the accumulation of mutations, leading to the formation of neoantigens and the activation of antitumor immune responses [52,53].

Of note, the proportion of MSI-H status among BTC patients is controversial, as suggested by recent studies on this topic reporting conflicting results [54]. In fact, a landmark whole exome-sequencing report conducted by Nakamura and colleagues highlighted concurrent dMMR or MSI-H status in 36\% of 260 BTC patients [55]. This proportion has been revised downward in a systematic review by Silva, estimating a proportion of dMMR and/or MSI-H of 10\%, 5\%-13\%, and 5\% in iCCA, eCCA, and GBC, respectively [56]. In addition, two reports by Weinberg and Winkelmann reported even lower proportions, with the former observing only 1\% of dMMR by immunohistochemistry in 102 BTC specimens; conversely, the latter highlighted only seven cases of MSI-H/dMMR in a cohort of 352 BTCs $(2 \%)[49,57]$.

As regards the predictive value of dMMR/MSI-H, few data are available so far. However, it is worth noting that in the previously discussed phase II trial on nivolumab monotherapy conducted by Kim and colleagues, all responders were microsatellite stable (MSS) [37]. Similarly, in the report by Zhang, the three BTC patients who achieved PR or CR with ICIs were all MSS [50]. In addition, the previously discussed KEYNOTE158 and KEYNOTE-028 trials exploring the role of pembrolizumab in pretreated patients with advanced BTC reported an interesting finding: in fact, all responders to the ICI were microsatellite stable, adding further confusion on the putative role of MSI [36]. Of note, 95.2\% (99/104) of the BTC patients enrolled in the KEYNOTE-158 were MSS, and pembrolizumab reported a disappointing response rate of $5.8 \%$, as previously reported [36]. Conversely, only one MSI-H patient was included in the KEYNOTE-028 study, where no data on MSI were available in $37.5 \%$ of the enrolled BTCs [36].

Although the scarcity of data precludes from making a strong statement regarding the effective role of $\mathrm{dMMR} / \mathrm{MSI}-\mathrm{H}$, available evidence seems to suggest an overall modest value of these biomarkers. Conversely, the evaluation of these biomarkers in concert with other potentially meaningful predictors could provide more useful information, as indicated by recently published studies on DDR, TMB, and MSI-H in this setting (Table 3). 
Table 3. Table reporting some possible advantages and disadvantages of the frequently used biomarkers for predicting the response to immunotherapy.

\begin{tabular}{|c|c|c|c|}
\hline Pros/Cons & PD-L1 & MSI-H/dMMR & TMB \\
\hline Advantages & $\begin{array}{l}\text { Easy, low-cost, } \\
\text { widely available }\end{array}$ & $\begin{array}{ll}\text { - } & \text { Available in all solid } \\
\text { malignancies } \\
\text { - } \quad \text { PCR or IHC for } \\
\text { determining dMMR }\end{array}$ & $\begin{array}{l}\text { - Available for the majority of } \\
\text { tumor types } \\
\text { - } \quad \text { Simultaneous detection of } \\
\text { other potential predictors }\end{array}$ \\
\hline Disadvantages & $\begin{array}{ll}- & \text { Multiple assays } \\
- & \text { Lack of standardization } \\
- & \text { Unknown optimum cutoff } \\
\text { - } & \text { threshold } \\
& \text { Positivity cutoff may vary } \\
\text { depending on tumor type } \\
\text { - } & \text { Accuracy for predicting } \\
& \text { response appears variable }\end{array}$ & $\begin{array}{ll}\text { - } & \text { Relatively rare finding } \\
\text { - } & \text { Best method to } \\
\text { determine MSI status } \\
\text { remains unclear }\end{array}$ & 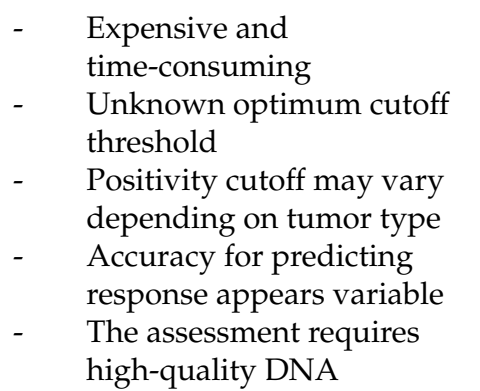 \\
\hline
\end{tabular}

dMMR, mismatch repair deficiency; IHC, immunohistochemistry; MSI-H, high microsatellite instability; PCR, polymerase chain reaction; PD-L1, programmed death-ligand 1; TMB, tumor mutational burden.

\section{DDR}

Among the most promising predictive biomarkers of the response to immunotherapy, recent years have witnessed growing attention toward DDR gene alterations, based on preclinical and early phase clinical trials supporting this biological rationale [58,59]. Of note, DDR gene aberrations impair DNA damage repair processes, with subsequent accumulation of DNA damage [60]; in physiological conditions, genes such as poly (ADP-ribose) polymerase 1 and 2 (PARP1 and PARP2) play a key role in maintaining genomic stability and in avoiding the accumulation of these mutations, with the inhibition of these genes representing a timely topic in medical oncology [61].

Based on these premises, mutations in DDR genes have been recently studied in BTC, reporting interesting data on their possible role and their impact on modifying the responses to ICIs [62]. First, the proportion of DDR gene mutations in BTC has been reported to occur in approximately $30 \%$ of patients, while Breast Related Cancer Antigens (BRCA) mutations seem to fluctuate between $1 \%$ and $7 \%$, according to previous reports [63-65]. A recently published study by Spizzo and colleagues analyzed tumor samples from 1292 BTC patients (iCCA, $n=746$; eCCA, $n=189$; GBC, $n=353$ ) using next-generation sequencing [66]. Of note, BRCA mutations were observed in $3.6 \%$ of tumor samples, without showing significant differences according to tumor site [66]; in addition, an important finding of this report is the association between BRCA mutations, MSI/dMMR, and TMB-H, something that supports the evaluation of ICIs in a specific subgroup of BTC patients, with DDR gene mutations potentially representing biomarkers predictive of the response to immunotherapy $[66,67]$.

Nonetheless, there is currently no consensus on the methods for testing DDR gene alterations and few data are available on the effective role of DDR gene mutations in BTC. Lastly, none of the recent studies investigating ICIs as a monotherapy or in combination with other anticancer agents in metastatic BTC have reported the number of patients harboring DDR aberrations; further studies are warranted in this direction to shed light on this promising - and still barely known-landscape.

\section{TME}

The tumor microenvironment (TME) represents another promising biomarker whose role as a predictor of the response to ICIs is under evaluation in several tumor types, 
with preclinical studies suggesting that TME could modify and modulate the host immune response against tumors [68-70]. As regards BTC, recent reports have highlighted that these hepatobiliary tumors are desmoplastic malignancies with the TME showing immunosuppressive innate immune cells, including tumor-associated macrophages and myeloid-derived suppressor cells [71-73]. In addition, the existence of distinct subgroups of tumors has been suggested, with immunologically "hot" and "cold" BTCs [74]. As regards the former, enhanced immune molecular expression, higher CD8+ T cell density, and a superior response rate to immunotherapy have been observed; in addition, this BTC subgroup seems to report increased PD-1 and PD-L1 expression, together with higher CD8+ T cell infiltration and enhanced granzyme B activity [75]. Conversely, the immune "cold" subgroup - which seems to represent the majority of these malignancies on the basis of the response rate observed in clinical trials assessing ICIs-presents a prevalence of immunosuppressive cells (e.g., tumor-associated macrophages and tolerogenic dendritic cells) and a non-T cell-infiltrated TME [75]. However, these results are still preliminary and offer an overall limited level of evidence.

\section{Conclusions}

ICIs are being assessed in advanced BTC, as a monotherapy or in combination with other anticancer agents, reporting controversial results so far; of note, most patients show disappointing clinical outcomes. Responses seem limited to a small percentage of BTCs. Unfortunately, the available data on the predictors of the response to ICIs in BTC are conflicting, and no single biomarker may select patients likely to benefit from this therapeutic approach. Moreover, we are aware that discussing potentially meaningful predictors could appear preliminary in a setting where immunotherapy is still trying to "find its way." However, the identification of reliable predictors of the response to immunotherapy represents a compelling and urgent need in this aggressive malignancy with limited treatment options.

Author Contributions: Conceptualization, A.R., A.D.R. and G.B.; methodology, A.R. and A.D.R.; software, A.R. and A.D.R.; validation, G.B.; formal analysis, A.R. and A.D.R.; investigation, A.R. and A.D.R.; resources, A.R. and A.D.R.; data curation, A.R. and A.D.R.; writing-original draft preparation, A.R. and A.D.R.; writing-review and editing, A.R. and A.D.R.; visualization, A.R., A.D.R. and G.B.; supervision, G.B.; project administration, A.R. and A.D.R.; funding acquisition, A.R. All authors have read and agreed to the published version of the manuscript.

Funding: This research received no external funding.

Institutional Review Board Statement: Not applicable.

Informed Consent Statement: Not applicable.

Data Availability Statement: Not applicable.

Conflicts of Interest: The authors declare no conflict of interest.

\section{References}

1. Razumilava, N.; Gores, G.J. Classification, diagnosis, and management of cholangiocarcinoma. Clin. Gastroenterol. Hepatol. 2013, 11, e13-e14. [CrossRef] [PubMed]

2. Rizzo, A.; Brandi, G. BILCAP trial and adjuvant capecitabine in resectable biliary tract cancer: Reflections on a standard of care. Expert Rev. Gastroenterol. Hepatol. 2020, 1-3. [CrossRef] [PubMed]

3. Banales, J.M.; Cardinale, V.; Carpino, G.; Marzioni, M.; Andersen, J.B.; Invernizzi, P.; Lind, G.E.; Folseraas, T.; Forbes, S.J.; Fouassier, L.; et al. Cholangiocarcinoma: Current knowledge and future perspectives consensus statement from the European Network for the Study of Cholangiocarcinoma (ENS-CCA). Nat. Rev. Gastroenterol. Hepatol. 2016, 13, 261-280. [CrossRef] [PubMed]

4. Rizvi, S.; Gores, G.J. Emerging molecular therapeutic targets for cholangiocarcinoma. J. Hepatol. 2017, 67, 632-644. [CrossRef]

5. Liau, J.Y.; Tsai, J.H.; Yuan, R.H.; Chang, C.N.; Lee, H.J.; Jeng, Y.M. Morphological subclassification of intrahepatic cholangiocarcinoma: Etiological, clinicopathological, and molecular features. Mod. Pathol. 2014, 27, 1163-1173. [CrossRef]

6. Tella, S.H.; Kommalapati, A.; Borad, M.J.; Mahipal, A. Second-line therapies in advanced biliary tract cancers. Lancet Oncol. 2020, 21, e29-e41. [CrossRef]

7. Bridgewater, J.; Galle, P.R.; Khan, S.A.; Llovet, J.M.; Park, J.W.; Patel, T.; Pawlik, T.M.; Gores, G.J. Guidelines for the diagnosis and management of intrahepatic cholangiocarcinoma. J. Hepatol. 2014, 60, 1268-1289. [CrossRef] 
8. Tariq, N.U.; McNamara, M.G.; Valle, J.W. Biliary tract cancers: Current knowledge, clinical candidates and future challenges. Cancer Manag. Res. 2019, 11, 2623-2642. [CrossRef]

9. Brandi, G.; Rizzo, A.; Dall'Olio, F.G.; Felicani, C.; Ercolani, G.; Cescon, M.; Frega, G.; Tavolari, S.; Palloni, A.; De Lorenzo, S.; et al. Percutaneous radiofrequency ablation in intrahepatic cholangiocarcinoma: A retrospective single-center experience. Int. J. Hyperth. 2020, 37, 479-485. [CrossRef]

10. Valle, J.; Wasan, H.; Palmer, D.H.; Cunningham, D.; Anthoney, A.; Maraveyas, A.; Madhusudan, S.; Iveson, T.; Hughes, S.; Pereira, S.P.; et al. Cisplatin plus gemcitabine versus gemcitabine for biliary tract cancer. N. Engl. J. Med. 2010, 362, 1273-1281. [CrossRef]

11. Valle, J.W.; Furuse, J.; Jitlal, M.; Beare, S.; Mizuno, N.; Wasan, H.; Bridgewater, J.; Okusaka, T. Cisplatin and gemcitabine for advanced biliary tract cancer: A meta-analysis of two randomised trials. Ann. Oncol. 2014, 25, 391-398. [CrossRef] [PubMed]

12. Valle, J.W.; Lamarca, A.; Goyal, L.; Barriuso, J.; Zhu, A.X. New Horizons for Precision Medicine in Biliary Tract Cancers. Cancer Discov. 2017, 7, 943-962. [CrossRef] [PubMed]

13. Lamarca, A.; Barriuso, J.; McNamara, M.G.; Valle, J.W. Molecular targeted therapies: Ready for "prime time" in biliary tract cancer. J. Hepatol. 2020, 73, 170-185. [CrossRef] [PubMed]

14. Massa, A.; Varamo, C.; Vita, F.; Tavolari, S.; Peraldo-Neia, C.; Brandi, G.; Rizzo, A.; Cavalloni, G.; Aglietta, M. Evolution of the Experimental Models of Cholangiocarcinoma. Cancers 2020, 12, 2308. [CrossRef] [PubMed]

15. Zou, S.; Li, J.; Zhou, H.; Frech, C.; Jiang, X.; Chu, J.S.; Zhao, X.; Li, Y.; Li, Q.; Wang, H.; et al. Mutational landscape of intrahepatic cholangiocarcinoma. Nat. Commun. 2014, 5, 5696. [CrossRef] [PubMed]

16. Abou-Alfa, G.K.; Sahai, V.; Hollebecque, A.; Vaccaro, G.; Melisi, D.; Al-Rajabi, R.; Paulson, A.S.; Borad, M.J.; Gallinson, D.; Murphy, A.G.; et al. Pemigatinib for previously treated, locally advanced or metastatic cholangiocarcinoma: A multicentre, open-label, phase 2 study. Lancet Oncol. 2020, 21, 671-684. [CrossRef]

17. Abou-Alfa, G.K.; Macarulla, T.; Javle, M.M.; Kelley, R.K.; Lubner, S.J.; Adeva, J.; Cleary, J.M.; Catenacci, D.V.; Borad, M.J.; Bridgewater, J.; et al. Ivosidenib in IDH1-mutant, chemotherapy-refractory cholangiocarcinoma (ClarIDHy): A multicentre, randomised, double-blind, placebo-controlled, phase 3 study. Lancet Oncol. 2020, 21, 796-807. [CrossRef]

18. Rizzo, A.; Ricci, A.D.; Brandi, G. Futibatinib, an investigational agent for the treatment of intrahepatic cholangiocarcinoma: Evidence to date and future perspectives. Expert Opin. Investig. Drugs 2020,1-8. [CrossRef]

19. Mazzaferro, V.; El-Rayes, B.F.; Droz dit Busset, M.; Cotsoglou, C.; Harris, W.P.; Damjanov, N.; Masi, G.; Rimassa, L.; Personeni, N.; Braiteh, F.; et al. Derazantinib (ARQ 087) in advanced or inoperable FGFR2 gene fusion-positive intrahepatic cholangiocarcinoma. Br. J. Cancer 2019, 120, 165-171. [CrossRef]

20. Rizzo, A.; Ricci, A.D.; Tavolari, S.; Brandi, G. Circulating Tumor DNA in Biliary Tract Cancer: Current Evidence and Future Perspectives. Cancer Genom. Proteom. 2020, 17, 441-452. [CrossRef]

21. Ma, B.; Meng, H.; Tian, Y.; Wang, Y.; Song, T.; Zhang, T.; Wu, Q.; Cui, Y.; Li, H.; Zhang, W.; et al. Distinct clinical and prognostic implication of IDH1/2 mutation and other most frequent mutations in large duct and small duct subtypes of intrahepatic cholangiocarcinoma. BMC Cancer 2020, 20, 318. [CrossRef] [PubMed]

22. Churi, C.R.; Shro_, R.; Wang, Y.; Rashid, A.; Kang, H.C.; Weatherly, J.; Zuo, M.; Zinner, R.; Hong, D.; Meric-Bernstam, F.; et al. Mutation Profiling in Cholangiocarcinoma: Prognostic and Therapeutic Implications. PLoS ONE 2014, 9, e115383. [CrossRef] [PubMed]

23. Chakrabarti, S.; Kamgar, M.; Mahipal, A. Targeted Therapies in Advanced Biliary Tract Cancer: An Evolving Paradigm. Cancers 2020, 12, 2039. [CrossRef] [PubMed]

24. Rizzo, A.; Ricci, A.D.; Brandi, G. Recent advances of immunotherapy for biliary tract cancer. Expert Rev. Gastroenterol. Hepatol. 2020, 20, 1-10. [CrossRef] [PubMed]

25. Morizane, C.; Ueno, M.; Ikeda, M.; Okusaka, T.; Ishii, H.; Furuse, J. New developments in systemic therapy for advanced biliary tract cancer. Jpn. J. Clin. Oncol. 2018, 48, 703-711. [CrossRef]

26. Vogel, A.; Bathon, M.; Saborowski, A. Immunotherapies in clinical development for biliary tract cancer. Expert Opin. Investig. Drugs 2020, 1-13. [CrossRef]

27. Reck, M.; Rodríguez-Abreu, D.; Robinson, A.G.; Hui, R.; Csőszi, T.; Fülöp, A.; Gottfried, M.; Peled, N.; Tafreshi, A.; Cuffe, S.; et al. Updated Analysis of KEYNOTE-024: Pembrolizumab Versus Platinum-Based Chemotherapy for Advanced Non-Small-Cell Lung Cancer With PD-L1 Tumor Proportion Score of 50\% or Greater. J. Clin. Oncol. 2019, 37, 537-546. [CrossRef]

28. Rizzo, A.; Mollica, V.; Ricci, A.D.; Maggio, I.; Massucci, M.; Rojas Limpe, F.L.; Fabio, F.D.; Ardizzoni, A. Third- and laterline treatment in advanced or metastatic gastric cancer: A systematic review and meta-analysis. Future Oncol. 2020, 16, 4409-4418. [CrossRef]

29. Powles, T.; Walker, J.; Andrew Williams, J.; Bellmunt, J. The evolving role of PD-L1 testing in patients with metastatic urothelial carcinoma. Cancer Treat. Rev. 2020, 82, 101925. [CrossRef]

30. Sabbatino, F.; Villani, V.; Yearley, J.H.; Deshpande, V.; Cai, L.; Konstantinidis, I.T.; Moon, C.; Nota, S.; Wang, Y.; Al-Sukaini, A.; et al. PD-L1 and HLA Class I Antigen Expression and Clinical Course of the Disease in Intrahepatic Cholangiocarcinoma. Clin. Cancer Res. 2016, 22, 470-478. [CrossRef]

31. Ye, Y.; Zhou, L.; Xie, X.; Jiang, G.; Xie, H.; Zheng, S. Interaction of B7-H1 on intrahepatic cholangiocarcinoma cells with PD-1 on tumor-infiltrating T cells as a mechanism of immune evasion. J. Surg. Oncol. 2009, 100, 500-504. [CrossRef] [PubMed] 
32. Fontugne, J.; Augustin, J.; Pujals, A.; Compagnon, P.; Rousseau, B.; Luciani, A.; Tournigand, C.; Cherqui, D.; Azoulay, D.; Pawlotsky, J.M.; et al. PD-L1 expression in perihilar and intrahepatic cholangiocarcinoma. Oncotarget 2017, 8, 24644-24651. [CrossRef] [PubMed]

33. Walter, D.; Herrmann, E.; Schnitzbauer, A.A.; Zeuzem, S.; Hansmann, M.L.; Peveling-Oberhag, J.; Hartmann, S. PD-L1 expression in extrahepatic cholangiocarcinoma. Histopathology 2017, 71, 383-392. [CrossRef] [PubMed]

34. Gani, F.; Nagarajan, N.; Kim, Y.; Zhu, Q.; Luan, L.; Bhaijjee, F.; Anders, R.A.; Pawlik, T.M. Program Death 1 Immune Checkpoint and Tumor Microenvironment: Implications for Patients with Intrahepatic Cholangiocarcinoma. Ann. Surg. Oncol. 2016, 23, 2610-2617. [CrossRef]

35. Ricci, A.D.; Rizzo, A.; Brandi, G. Immunotherapy in Biliary Tract Cancer: Worthy of a Second Look. Cancer Control 2020, 27, 1073274820948047. [CrossRef]

36. Piha-Paul, S.A.; Oh, D.Y.; Ueno, M.; Malka, D.; Chung, H.C.; Nagrial, A.; Kelley, R.K.; Ros, W.; Italiano, A.; Nakagawa, K.; et al. Efficacy and safety of pembrolizumab for the treatment of advanced biliary cancer: Results from the KEYNOTE-158 and KEYNOTE-028 studies. Int. J. Cancer 2020, 147, 2190-2198. [CrossRef]

37. Kim, R.D.; Chung, V.; Alese, O.B.; El-Rayes, B.F.; Li, D.; Al-Toubah, T.E.; Schell, M.J.; Zhou, J.M.; Mahipal, A.; Kim, B.H.; et al. A Phase 2 Multi-institutional Study of Nivolumab for Patients with Advanced Refractory Biliary Tract Cancer. JAMA Oncol. 2020, 6, 888-894. [CrossRef]

38. Ancevski Hunter, K.; Socinski, M.A.; Villaruz, L.C. PD-L1 Testing in Guiding Patient Selection for PD-1/PD-L1 Inhibitor Therapy in Lung Cancer. Mol. Diagn. Ther. 2018, 22, 1-10. [CrossRef]

39. Lemery, S.; Keegan, P.; Pazdur, R. First FDA Approval Agnostic of Cancer Site-When a Biomarker Defines the Indication. N. Engl. J. Med. 2017, 377, 1409-1412. [CrossRef]

40. Ueno, M.; Ikeda, M.; Morizane, C.; Kobayashi, S.; Ohno, I.; Kondo, S.; Okano, N.; Kimura, K.; Asada, S.; Namba, Y.; et al. Nivolumab alone or in combination with cisplatin plus gemcitabine in Japanese patients with unresectable or recurrent biliary tract cancer: A non-randomised, multicentre, open-label, phase 1 study. Lancet Gastroenterol. Hepatol. 2019, 4, 611-621. [CrossRef]

41. Ioka, T.; Ueno, M.; Oh, D.Y.; Fujiwara, Y.; Chen, J.S.; Doki, Y.; Mizuno, N.; Park, K.; Asagi, A.; Hayama, M.; et al. Evaluation of safety and tolerability of durvalumab (D) with or without tremelimumab (T) in patients (pts) with biliary tract cancer (BTC). J. Clin. Oncol. 2019, 37, 387. [CrossRef]

42. Yoo, C.; Oh, D.Y.; Choi, H.J.; Kudo, M.; Ueno, M.; Kondo, S.; Chen, L.T.; Osada, M.; Helwig, C.; Dussault, I.; et al. Phase I study of bintrafusp alfa, a bifunctional fusion protein targeting TGF- $\beta$ and PD-L1, in patients with pretreated biliary tract cancer. $J$. Immunother. Cancer 2020, 8, e000564. [CrossRef] [PubMed]

43. Ritterhouse, L.L. Tumor mutational burden. Cancer Cytopathol. 2019, 127, 735-736. [CrossRef] [PubMed]

44. McNamara, M.G.; Jacobs, T.; Lamarca, A.; Hubner, R.A.; Valle, J.W.; Amir, E. Impact of high tumor mutational burden in solid tumors and challenges for biomarker application. Cancer Treat. Rev. 2020, 89. [CrossRef] [PubMed]

45. Yarchoan, M.; Hopkins, A.; Jaffee, E.M. Tumor Mutational Burden and Response Rate to PD-1 Inhibition. N. Engl. J. Med. 2017, 377, 2500-2501. [CrossRef]

46. Goodman, A.M.; Kato, S.; Bazhenova, L.; Patel, S.P.; Frampton, G.M.; Miller, V.; Stephens, P.J.; Daniels, G.A.; Kurzrock, R. Tumor Mutational Burden as an Independent Predictor of Response to Immunotherapy in Diverse Cancers. Mol. Cancer Ther. 2017, 16, 2598-2608. [CrossRef]

47. Wang, Z.; Duan, J.; Cai, S.; Han, M.; Dong, H.; Zhao, J.; Zhu, B.; Wang, S.; Zhuo, M.; Sun, J.; et al. Assessment of Blood Tumor Mutational Burden as a Potential Biomarker for Immunotherapy in Patients with Non-Small Cell Lung Cancer With Use of a Next-Generation Sequencing Cancer Gene Panel. JAMA Oncol. 2019, 5, 696-702. [CrossRef]

48. Chalmers, Z.R.; Connelly, C.F.; Fabrizio, D.; Gay, L.; Ali, S.M.; Ennis, R.; Schrock, A.; Campbell, B.; Shlien, A.; Chmielecki, J.; et al. Analysis of 100,000 human cancer genomes reveals the landscape of tumor mutational burden. Genome Med. 2017, 9, 34. [CrossRef]

49. Weinberg, B.A.; Xiu, J.; Lindberg, M.R.; Shields, A.F.; Hwang, J.J.; Poorman, K.; Salem, M.E.; Pishvaian, M.J.; Holcombe, R.F.; Marshall, J.L.; et al. Molecular profiling of biliary cancers reveals distinct molecular alterations and potential therapeutic targets. J. Gastrointest. Oncol. 2019, 10, 652-662. [CrossRef]

50. Zhang, W.; Shi, J.; Wang, Y.; Zhou, H.; Zhang, Z.; Han, Z.; Li, G.; Yang, B.; Cao, G.; Ke, Y.; et al. Next-generation sequencing-guided molecular-targeted therapy and immunotherapy for biliary tract cancers. Cancer Immunol. Immunother. 2020. [CrossRef]

51. Dudley, J.C.; Lin, M.T.; Le, D.T.; Eshleman, J.R. Microsatellite Instability as a Biomarker for PD-1 Blockade. Clin. Cancer Res. 2016, 22, 813-820. [CrossRef] [PubMed]

52. Ganesh, K.; Stadler, Z.K.; Cercek, A.; Mendelsohn, R.B.; Shia, J.; Segal, N.H.; Diaz, L.A., Jr. Immunotherapy in colorectal cancer: Rationale, challenges and potential. Nat. Rev. Gastroenterol. Hepatol. 2019, 16, 361-375. [CrossRef] [PubMed]

53. Chang, L.; Chang, M.; Chang, H.M.; Chang, F. Microsatellite Instability: A Predictive Biomarker for Cancer Immunotherapy. Appl. Immunohistochem. Mol. Morphol. 2018, 26, e15-e21. [CrossRef] [PubMed]

54. Verlingue, L.; Malka, D.; Allorant, A.; Massard, C.; Ferte, C.; Lacroix, L.; Rouleau, E.; Auger, N.; Ngo, M.; Nicotra, C.; et al. Precision medicine for patients with advanced biliary tract cancers: An effective strategy within the prospective MOSCATO-01 trial. Eur. J. Cancer 2017, 87, 122-130. [CrossRef]

55. Nakamura, H.; Arai, Y.; Totoki, Y.; Shirota, T.; Elzawahry, A.; Kato, M.; Hama, N.; Hosoda, F.; Urushidate, T.; Ohashi, S.; et al. Genomic spectra of biliary tract cancer. Nat. Genet. 2015, 47, 1003-1010. [CrossRef] 
56. Silva, V.W.; Askan, G.; Daniel, T.D.; Lowery, M.; Klimstra, D.S.; Abou-Alfa, G.K.; Shia, J. Biliary carcinomas: Pathology and the role of DNA mismatch repair deficiency. Chin. Clin. Oncol. 2016, 5, 62. [CrossRef]

57. Winkelmann, R.; Schneider, M.; Hartmann, S.; Schnitzbauer, A.A.; Zeuzem, S.; Peveling-Oberhag, J.; Hansmann, M.L.; Walter, D. Microsatellite Instability Occurs Rarely in Patients with Cholangiocarcinoma: A Retrospective Study from a German Tertiary Care Hospital. Int. J. Mol. Sci. 2018, 19, 1421. [CrossRef]

58. Brown, J.S.; O'Carrigan, B.; Jackson, S.P.; Yap, T.A. Targeting DNA Repair in Cancer: Beyond PARP Inhibitors. Cancer Discov. 2017, 7, 20-37. [CrossRef]

59. Yap, T.A.; Plummer, R.; Azad, N.S.; Helleday, T. The DNA Damaging Revolution: PARP Inhibitors and Beyond. Am. Soc. Clin. Oncol. Educ. Book 2019, 39, 185-195. [CrossRef]

60. Rizzo, A.; Mollica, V.; Cimadamore, A.; Santoni, M.; Scarpelli, M.; Giunchi, F.; Cheng, L.; Lopez-Beltran, A.; Fiorentino, M.; Montironi, R.; et al. Is There a Role for Immunotherapy in Prostate Cancer? Cells 2020, 9, 2051. [CrossRef]

61. Pilié, P.G.; Tang, C.; Mills, G.B.; Yap, T.A. State-of-the-art strategies for targeting the DNA damage response in cancer. Nat. Rev. Clin. Oncol. 2019, 16, 81-104. [CrossRef] [PubMed]

62. Reisländer, T.; Groelly, F.J.; Tarsounas, M. DNA Damage and Cancer Immunotherapy: A STING in the Tale. Mol. Cell 2020, 80, 21-28. [CrossRef] [PubMed]

63. Lamarca, A.; Barriuso, J.; McNamara, M.G.; Valle, J.W. Biliary Tract Cancer: State of the Art and potential role of DNA Damage Repair. Cancer Treat. Rev. 2018, 70, 168-177. [CrossRef] [PubMed]

64. Golan, T.; Raitses-Gurevich, M.; Kelley, R.K.; Bocobo, A.G.; Borgida, A.; Shroff, R.T.; Holter, S.; Gallinger, S.; Ahn, D.H.; Aderka, D.; et al. Overall Survival and Clinical Characteristics of BRCA-Associated Cholangiocarcinoma: A Multicenter Retrospective Study. Oncologist 2017, 22, 804-810. [CrossRef]

65. Abdel-Wahab, R.; Yap, T.A.; Madison, R.; Pant, S.; Cooke, M.; Wang, K.; Zhao, H.; Bekaii-Saab, T.; Karatas, E.; Kwong, L.N.; et al. Genomic profiling reveals high frequency of DNA repair genetic aberrations in gallbladder cancer. Sci. Rep. 2020, 10, 22087. [CrossRef]

66. Spizzo, G.; Puccini, A.; Xiu, J.; Goldberg, R.M.; Grothey, A.; Shields, A.F.; Arora, S.P.; Khushmann, M.; Salem, M.E.; Battaglin, F.; et al. Molecular profile of BRCA-mutated biliary tract cancers. ESMO Open 2020, 5, e000682. [CrossRef]

67. Ricci, A.D.; Rizzo, A.; Brandi, G. The DNA damage repair (DDR) pathway in biliary tract cancer (BTC): A new Pandora's box? ESMO Open 2020, 5, e001042. [CrossRef]

68. Wu, T.; Dai, Y. Tumor microenvironment and therapeutic response. Cancer Lett. 2017, 387, 61-68. [CrossRef]

69. Hui, L.; Chen, Y. Tumor microenvironment: Sanctuary of the devil. Cancer Lett. 2015, 368, 7-13. [CrossRef]

70. Frankel, T.; Lanfranca, M.P.; Zou, W. The Role of Tumor Microenvironment in Cancer Immunotherapy. Adv. Exp. Med. Biol. 2017, 1036, 51-64.

71. Mertens, J.C.; Rizvi, S.; Gores, G.J. Targeting cholangiocarcinoma. Biochim. Biophys. Acta Mol. Basis Dis. 2018, 1864, 1454-1460. [CrossRef] [PubMed]

72. Fabris, L.; Sato, K.; Alpini, G.; Strazzabosco, M. The Tumor Microenvironment in Cholangiocarcinoma Progression. Hepatology 2020. [CrossRef] [PubMed]

73. Romano, M.; De Francesco, F.; Gringeri, E.; Giordano, A.; Ferraro, G.A.; Di Domenico, M.; Cillo, U. Tumor Microenvironment Versus Cancer Stem Cells in Cholangiocarcinoma: Synergistic Effects? J. Cell. Physiol. 2016, 231, 768-776. [CrossRef] [PubMed]

74. Wu, H.J.; Chu, P.Y. Role of Cancer Stem Cells in Cholangiocarcinoma and Therapeutic Implications. Int. J. Mol. Sci. 2019, 20, 4154. [CrossRef]

75. Loeuillard, E.; Conboy, C.B.; Gores, G.J.; Rizvi, S. Immunobiology of cholangiocarcinoma. JHEP Rep. 2019, 1, 297-311. [CrossRef] 